\title{
MÄDCHEN IN UNIFORM - GENDER, POWER AND SEXUALITY IN TIMES OF MILITARISATION
}

\author{
Gerda-Elisabeth Wittmann \\ North-West University, Potchefstroom Campus \\ Ian Liebenberg \\ Faculty of Military Science, Stellenbosch University
}

\begin{abstract}
The film Mädchen in Uniform (1931), a love story between a teacher and student in Germany, is widely recognised as the first pro-lesbian film. Banned by the National Socialists, it opened the way for pro-lesbian film production and was followed by films such as Acht Mädels im Boot (1932), Anna and Elisabeth (1933) and Ich für dich, du für mich (Me for You, You for Me, 1934). These films strongly contrasted with documentaries and popular films of the Third Reich that portrayed a new and heroic German nation growing from the ashes of defeat following the uneasy Peace of Versailles. The film Aimée \& Jaguar (1999) revisited the theme of lesbian love during the National Socialist regime. Based on a true story, the film is a narrative of the love between a German and a Jewish woman. Despite controversy, the film won numerous prizes in Germany. This article investigates the portrayal of gender and power in Mädchen in Uniform and Aimée \& Jaguar. It seeks to explain how lesbian women and the love between them were portrayed in a time of male domination, militarism and what was seen as hetero-normality. This contribution examines gender-related power struggles and the political climate in Germany at the time of the Weimar Republic and the build-up to National-Socialist militarism.
\end{abstract}

\section{Introduction}

This article deals with a case study of filmic art that illustrates the tensions between the somatic search for freedom and the constraints of a society that longed

Scientia Militaria, South African Journal of Military Studies, Vol 41, Nr 1, 2013, pp. 138-154. doi: $10.5787 / 41-1-1056$ for law, order, authority, and, if needs be, military force. The Weimar Republic was established in a Germany that suffered defeat in the First World War (1914-1918) and 
accepted peace terms that many viewed as harsh and unattainable. ${ }^{1}$ For the people of Germany, the Weimar Republic spelled the old and new in social identities and culture. $^{2}$ Contradictory as it may seem, it was a time of freedom amidst insecurity and political strife, worsened by economic woe. While the military felt both defeated and betrayed after World War I, the Weimar Republic saw the rise of liberal and social democratic parties that advocated a democratic state where all citizens had access to social rights at the behest of the new state. ${ }^{3}$ Women were allowed, for the first time, to participate in the National Assembly elections. At the same time, extreme nationalists and those with a militarist inclination saw the Weimar politicians as "puppets" and the disgust with Versailles turned into a fight against the "Weimar system". Political assassinations (some by nationalistic and militarist groupings) and murders took place with regularity. The death of Matthias Erzberger, Walter Rathenau, Rosa Luxemburg and Karl Liebknecht (the latter Marxist activists) are notable. ${ }^{5}$

In what McCormick calls a "crisis of modernization", 6 economic, social and political modernisation triggered male anxieties when centuries of patriarchal relations seemed to come to an end. The traditional order and the individual's fixed sense of identity became destabilised by industrialisation, technology, warfare, postwar trauma and the emergence of post-conflict identities. The awareness of crises had social implications that touched both the individual and society. ${ }^{7}$ This new fluidity inspired fear for the new and uncertain, and a desire for liberation from traditional norms. One area in which these post-World War 1 social tensions, contradictions and the search for new freedoms in Germany are vividly illustrated, is in the world of the arts.

While men started questioning their roles and their existence, women became increasingly visible in the public sphere. From 1908, female students were allowed to attend German universities. During World War 1, they were able to expand their participation in the labour market. In cinemas, women were not only visible as actors on the screen, but they also made up the majority of the audience. The emancipation and sexual liberation of women posed a threat to the male population and a "castration anxiety", 8 both of which were evident in a number of art forms, including film.

Mandy Merck ${ }^{9}$ claims that if "lesbianism hadn't already existed, art cinema might have invented it. To cinema which affects an attitude of high seriousness in matters sexual, the lesbian romance affords a double benefit". Anneke Smelik asserts, "[h]omosexuality in cinema has been there since the movies began. Homosexual characters could be glimpsed in films - as they can still be today."10 Art cinema has been producing films with lesbian/gay/bisexual/transgender/intersex 
(LGBTI) characters for decades. German queer cinema has a wide following - and not only in Germany - so, perhaps there is value in considering the origin and context(s) of these films.

What made it possible to produce Mädchen in Uniform (1931) and other LGBTI movies in the Weimar Republic? In the study on which this article reports, we also investigated the power structure in Mädchen in Uniform, compared with Aimée \& Jaguar, set in a similar time but produced much later. Even though prominent antifascist film critics such as Karkauer and Lotte Eisner saw Mädchen in Uniform as a film about the formation of German identity in the Weimar Republic ${ }^{11}$ and the way this identity was threatened by the rise of National Socialism, the argument by Richs and Zimmik that it is a film about lesbianism and the forbidden love between women, as is Aimée \& Jaguar, also seems convincing. In Germany, following the insecurities of the Peace of Versailles, contrasting ideologies were in deep conflict. Social democrats, communists, socialist parties and right-wing ideologues attempted to win over the public - by force, if necessary. At such times, authoritarian ideologies frequently bloom. As a comprehensive worldview, an ideology attempts not only to describe a new world but also provides a programme of action appealing to the masses to enact such (simplified) view in order to usurp political power. While some were in search of greater individual and social freedoms, reactionary ideologies (or backward-looking worldviews) such as National Socialism were asserting themselves. ${ }^{1}$

\section{Methodology}

We analysed the portrayal of gender and power in the two German lesbian films, Mädchen in Uniform and Aimée \& Jaguar, and the ways in which lesbian women and the love between them was portrayed against the background of a period of male domination and hetero-normativity. As a sub-text, socialisation in an increasingly (re-)militarised society play a role and social identity groups resistant to the impositions of social control are addressed. The article further reports on the political climate in Germany that influenced the making of these films as well as the gender-related power struggles in them.

A multidisciplinary approach, mostly relying on gender perspectives including LGBTI studies, forms the theoretical background of this article. ${ }^{12}$ The relevant films are analysed with reference to their plots and the times they portray. 
Theoretical political and sociological literature relating to the Weimar Republic, National Socialism and German cinema was consulted in combination with secondary sources, especially articles, on the above-mentioned films. In addition, the article uses secondary literature on the socio-political developments in the Weimar Republic to contrast a surge for new freedoms and individualism during this period with the elements that drove a return through National Socialism to a hierarchical and, to a large extent, simplified male, militarist and racist order. ${ }^{13}$ The authors take qualified note of the work of Thomas Hanna (1972) that the imposition of regimental top-down orders, including what Hanna calls "traditional culture", leads frequently to theoretical and practical human resistance (Hanna refers to the "bodily revolt"). In a deeper sense, the counter culture that underpins these non-conventional manifestations of art implies resistance to uniformity and dictatorship by practising individuality. ${ }^{14}$ The Weimar Republic, despite the deep-seated animosities between its political actors, provided the space for such activity and a search for freedom by individuals and social identity groups uncomfortable with top-down impositions.

\section{Weimar Cinema}

Mädchen in Uniform and Aimee \& Jaguar share similarities in the sense that both films deal with the (physical) love between women before or during the Second World War. Yet, there are differences.

Mädchen in Uniform, based on the play Gestern und heute (Yesterday and Today, 1930) by Christa Winsloe (alias the Baroness von Hatvany) and republished as a novel, The Child Manuela, was filmed by Leontine Sagan in Germany in $1931^{15}$ and is an authentic product of the Weimar Republic. The film enjoyed astonishing popularity until it was banned by the National Socialists as being politically incorrect. As with most authoritarian regimes, then and later, films and art that do not support the totalising project of strong statehood and nationalist aspirations, were seen as subversive and destructive to the new ideologically laden mass morality. ${ }^{16}$ The film fell into a seeming limbo between silent German expressionist cinema and Third Reich products and was redeemed only as late as the 1970s by a cycle of women's film festivals. Ruby Rich $^{17}$ convincingly highlights the film's importance in the development of lesbian filmmaking when she observes,

Mädchen in Uniform is an exemplary work, not only for what it presents to us on the screen, but also for the timely issues that its analysis must confront. It is the film revival most key to establishing a history of lesbian cinema. 
Apart from its lesbian theme, the film was ground-breaking for other reasons: first, for its all-female cast; second, for its sympathetic portrayal of lesbian pedagogical eros and homoeroticism revolving around the passionate love of a fourteen-year-old girl for her teacher; and, third, for the cooperative and profitsharing financial arrangements of its production, rather than an emphasis on naked profit and a reliance on the free market military industrial spin-offs.

Despite its status as the first openly lesbian film, it is available only in $\mathrm{VHS}^{18}$ format, with poor sound quality and inadequate English, Spanish and Portuguese subtitles. The visible effects of years of censorship are still clear. ${ }^{19}$

Aimee \& Jaguar, which had a male director, Max Färberböck, as opposed to the female director, Leontine Sagan of Mädchen in Uniform, was based on Erica Fischer's novel, Aimée und Jaguar: Eine Liebesgeschichte Berlin 1943. Like Mädchen in Uniform, it is based on the true story of a German woman called Lilly Wust. The book published in Germany in 1994, turned into a bestseller. It was translated into eleven languages and gave rise to a series of art exhibitions. The English translation of Aimée \& Jaguar: A Love Story, Berlin 1943 won a Lambda Literary Award in 1995. The film was Germany's Oscar nomination for the year $2000 .^{20}$

Both films are contextually bound with the Weimar Republic in Germany, a time marked by deep ambivalence. On the one hand, the troubled Weimar Republic is remembered for its political instability, hyperinflation and poverty. On the other hand, these times was also described as "Die goldenen Zwanziger" (The golden 20s). The more traditional Wilhemine values that dominated social norms during the Kaiserreich were discredited as a consequence of World War I and subsequent inflation. What many saw as a bourgeoisie mentality was less popular. The new generation saw no point in saving for marriage in such conditions and preferred instead to spend and enjoy. While people enjoyed hitherto unknown freedoms and liberties, existential anxiety was notably evident in the arts. McCormick captures the feeling of insecurity with which the male population, in particular, struggled:

This language is easy to read psychoanalytically - fear of the female, fear of flaccidity, desire for a mythical phallic rigidity - and it is typical of the far Right during the Weimar Republic, as Klaus Theleweit demonstrates with text after text in Male Fantasies, his exhaustive psychoanalytical study of German misogyny and its relation to fascism. ${ }^{21}$

This existential male anxiety, which was often projected towards females, was not limited to right-wing movements, although such anxieties may have been 
more overt in the right wing socio-political sphere. Berlin was one example where the world of art embraced new elements of freedom, and the city became known for its avant-garde arts. Dadaism, known for cultural anarchist attacks on bourgeois art and literature often associated with women, was aligned with the left wing in Germany, and flourished. In fact, one of the protagonists of Dadaism, George Grosz, coined the phrase "Dada über Alles". ${ }^{22}$ In their manifesto, Dadaists furthermore claimed that the sexual criminal, Anton was a Dadaist when he wrote in his diary, "Killed today a young girl, it was fine and hot." ${ }^{, 3}$ Clearly, the roots of gender power contention in such a quote are not clear cut and deserve reflection in future studies. ${ }^{24}$

Stage productions by Max Reinhardt, Bertolt Brecht and Kurt Weill were to be seen. Berlin's art, music scene and cinema flourished, even amidst hyperinflation. ${ }^{25}$ Deliberate citations and portrayals of sexual brutality were included in artists' work in an attack against bourgeois morality and sentimentality. ${ }^{26}$ The poor lived in Mietskasernen ${ }^{27}$ and marching men belonged to the different factions that included the right-wing Freikorps and later the Sturmabteilung (SA) in contrast to bohemianism and a musical revolution. ${ }^{28}$ Associational life and civil societies flourished, while political institutions remained weak and politics confusing. ${ }^{29}$ Despite the insecurity and instability, interest in politics still remained. Art was increasingly politicised, ${ }^{30}$ as was the world of film. ${ }^{31}$

Silberman ${ }^{32}$ comments on the role of politics and society in Weimar cinema as follows, "all films may be seen as refracting lenses that reveal more or less clearly the needs, desires and fears of a society" and he goes on,

During the 1920's Germany saw the rise of the earliest and most sustained efforts at an alternate oppositional political cinema. The existence of two well-organised working class parties [...] as well as the strong cultural ties between the young Soviet Union and newly republican Germany created the framework for an unprecedented surge of politically motivated activity in all areas of cinema. ${ }^{33}$

Germany saw an unprecedented surge in politically motivated filmmaking, spurred on by two well-organised working class parties, the German Social Democratic Party (Sozialdemokratische Partei Deutschlands, SPD) and the German Communist Party (Kommunistische Partei Deutschlands, KPD). Partly because of their ties to the young Soviet Union, the seed for what would become known as radical left-wing cinema was planted. Both the SPD and the KPD produced short documentaries focusing on the plight and poverty of the workers. The avant-garde left, most prominently Brecht and Walter Benjamin, quickly discovered cinema as a way of revolutionising ideas about representation and art. ${ }^{34}$ During the Weimar Republic (1918-1933), a fluid political climate existed that facilitated the 
development and publication of LGBTI-themed movies. The gay and lesbian presence in the Weimar Republic was relatively public for the time. Gay and lesbian bars, organisations and publications were widespread. One convincing index of the pervasiveness of gay and lesbian life during the Weimar Republic can be found in films. Richard Dyer stresses the relevance of Weimar LGBTI films internationally:

Taken in isolation, these few films may appear a trickle, but in a context of lesbian/gay representation in film worldwide, they constitute a virtual avalanche. Most surveys and filmographies of homosexual images in film list only a handful of examples before the fifties, most of which represent homosexuality only momentarily or obliquely. By far the majority of these, and the only really substantial ones, are from Germany between 1918 and $1933 .{ }^{35}$

Anders als die Anderen, an Aufklärungsfilm (sexual enlightenment film) that researchers of LGBTI have long venerated, is generally seen as "the first work of cinema in which homosexuality is placed 'centrally, unambiguously and positively". ${ }^{36}$ Produced in the brief period (1919-1920) when censorship was suspended, it deals with the devastating effect of Paragraph $175^{37}$ on a homosexual male's life. While male-dominated films overshadowed the scene, Mädchen in Uniform (1931) was also produced. Lesbian film production was less risky than male homosexual film production as the German penal code did not recognise lesbianism and therefore did not outlaw it in terms of Paragraph 175. Despite being banned by the National Socialist government after Adolf Hitler came to power, Mädchen in Uniform enjoyed tremendous initial popularity, and was hailed as "one of the earliest and most powerful cinematic examples of lesbian attraction". 38

The freedom queer filmmakers enjoyed was short-lived. In 1926-1927, the wider economic crisis, bringing with it rising production costs and an increasing number of US imports, hit the German film industry. It even threatened the existence of Germany's largest production company, Ufa. The German media magnate Alfred Hugenberg acquired the majority holding in Ufa, bought out American interests in the sector and restructured the company along Hollywood populist lines. When the National Socialist regime came to power, Hugenberg was made Minister of Economics. The cooperation between him and Minster of Propaganda, Heinrich Goebbels, soon moved German cinema away from Weimar freedom to centralised Third Reich filmmaking. ${ }^{39}$ Nationalism and militarism returned centre stage. 


\section{Power relations in Mädchen in Uniform and Aimée und Jaguar}

Mädchen in Uniform centres on the relationship between the young female student, Manuela, and her teacher, Fräulein Von Bernburg. The complete absence of male characters immediately strikes the viewer. The radical concentration on female characters in combination with the film's strong antifascist, antimilitary message makes it even more remarkable. ${ }^{40}$

Manuela, the main character, is a new student at a Potsdam boarding school for the daughters of German officers. ${ }^{41}$ Manuela's mother is dead, her father unable to care for her ${ }^{42}$ and, with only her icily uncaring aunt as her guardian, Manuela craves affection. Fräulein Von Bernburg is the school's most popular teacher who, with her maternalistic humanitarianism, stands in stark contrast to the school's militaristic Prussian codes. This caring attitude is accompanied by repressed existential/human sexuality right from the start.

On Manuela's first night at the school, Fräulein Von Bernburg can be seen kissing the girls goodnight on the forehead. Ruby Rich ${ }^{43}$ observes -

The extreme fetishizing of the kiss, by both the nature of the teacher's gestures and director Sagan's cinematographic style, is emblematic of the unspoken codes of repressive tolerance. The kiss is permitted, to each alike, but it is at once the given and the boundary. Nothing more may be allowed or even suggested, although the tension of that which is withheld suffuses the scene with its eroticism of shimmering light and grants the teacher her very power. The kiss is the minimum and the maximum, a state of grace and a state of stasis. The entire equilibrium is founded upon this extreme tension - which is snapped when Manuela, overwhelmed by the atmosphere and her feelings, breaks the rules. She throws her arms around Fräulein von Bernburg's body in a tight embrace and receives, not a punishment, but a kiss. A kiss, not merely on the forehead, but full on the lips [author's italics].

Conceivably the fragile power equilibrium is disturbed by the impulsive gesture of affection between the much older teacher and the passionate, yet so naive student. At a later stage, Fräulein Von Bernburg gives Manuela her old clothes and undergarments, and thereby supplies the girl with a fetishistic token. ${ }^{44}$ When discovered, she tries to justify her act to the headmistress with the words, "Manuela was poorly equipped [...] The girl does not have a mother." 
Aimée \& Jaguar, in contrast, is the love story between two grown women, at least one of whom has no doubt about her homosexual orientation. Felice Schragenheim, alias Schrader, is the centre of an active group devoted to the lesbian highlife. She is a Jew working undercover for the Nazi press in order to obtain covert information for her contacts abroad. Apart from intelligence gathering, she helps people to obtain forged documents enabling them to leave, or to stay, in Germany. Lilly Wust seems to be the direct opposite of Felice. She is married to a low-ranking member of the Waffen SS, is the proud mother of four sons, seems heterosexual and shamelessly parrots National Socialist propaganda. ${ }^{45}$ Amongst other things, she is proud of her conceived ability to "smell a Jew". They meet through Lilly's domestic worker, Ilse, and, in spite of Lilly's initial anti-Semitic attitudes, a love affair soon follows.

Even though Aimée \& Jaguar was not, like Mädchen in Uniform, produced during the Weimar Republic, the story graphically carries traits of the era. Felice and her friends are typical examples of female intellectuals during the Weimar Republic. They are all unmarried; many of them are either bi- or homosexual, and they are unanimously determined to enjoy their sexual freedom. They are furthermore very visible, loud and opinionated, rebelling against the traditional role of the woman as nothing but a wife and mother. When Felice meets Lilly, she is still involved in an affair with Ilse, Lilly's domestic worker. She nevertheless pursues Lilly, and the resulting exclusive relationship between Lilly and Felice is not planned; it just seems to happen.

It is clear that, in addition to the taboo of being homosexual relationships, both relationships would have been regarded as intolerable in the circumstances and context in which they took place. Relationships between teachers and students were and still are frowned upon, if not directly forbidden. A relationship between a German and Jew would have been classified as an "interracial affair", according to Nazi terminology, ${ }^{46}$ and therefore illegal. ${ }^{47}$ As portrayed in the films, the fact that these were lesbian relationships almost seems like the lesser evil. In both works, there are implicit as well as explicit references to sexual relationships between women, which are portrayed as stable, loving and safe, whereas heterosexual relationships seem more dangerous or imprisoning choices.

Lotte, the only true heterosexual in Felice's circle of friends, stereotypically is known for her infidelity. When the friends make a trip to the local photographer, they are joined by Lotte, who complains that her boyfriend always says goodbye as if they would never see each other again. One of the others jokes is "Lotte and her men, don't start with that stuff." 48 This seemingly dismal episode gains relevance shortly thereafter in an example of dramatic irony when Lotte, the heterosexual who 
has "problems" with men, is killed in an unrelated incident by trench-coated Nazi henchmen, while the lesbian and bisexual girls all escape unharmed. ${ }^{49}$

Men are almost completely absent in Mädchen in Uniform; they are just referred to by the totalitarian school principal. On the rare occasions that men do appear, it is as "monuments of Prussianism or antique fighters, or, if you will, transfigured into the character of the mannish headmistress who is a dead ringer for Fredrick the Great". ${ }^{50}$ On their first day of school, Manuela and the other girls are reminded by the headmistress of their duty and identity. "You are all soldiers' daughters and, God willing; you will all be soldiers' mothers." ${ }^{, 1}$ In the absence of male figures, the principal takes over as the incarnation of the controlling patriarchy. Rich argues convincingly -

her identity as the "phallic woman" is suggested by her reliance on her ever present cane, with which she measures her steps and signals her authority, and by the phallocentric codes of Kinder, Kirche, Küche ${ }^{52}$ which she is dedicated to instilling ${ }^{53}$.

One could even argue that in the absence or inability of their fathers, these "girls in uniform" are forced to take on the role of soldiers themselves in the barren boarding school. Male or patriarchal figures are portrayed in both cases at the very least as dissatisfactory, if not as repressive, even dangerous, opponents.

Both films can be described as anti-patriarchal. The only references to men in Mädchen in Uniform are to the principal and her comment about the futures her pupils may expect to have. Male figures in Aimée \& Jaguar are clearly shown as opponents of women's happiness and self-fulfilment. Even the most benign male characters, Lilly's four sons, are sent away from their mother to live in safer rural areas. Only after her sons had left her, can Lilly enjoy true happiness with Felice.

The films are not primarily constructed around an anti-patriarchal theme, although patriarchy is equated in both of them with authority and militarism. Rich's ${ }^{54}$ assessment of Mädchen in Uniform as an anti-fascist film could just as easily apply to Aimée \& Jaguar:

However, most important to the film's reputation through the years has been its significance as an antiauthoritarian and prophetically anti-fascist film. To be sure, the film has suitable credentials for such a claim. Any film so opposed to militarism, so Anti-Prussian, so much in support of the emotional freedom of women, must be an anti-fascist film. 
Things are more complex. Not everything is black or white, least so in human culture, social identities, groups and the somatic/bodily beings constituting vexed relationships. In these films, there are salient gender-role-related power struggles even in the fundamentally sound relationships. Alice Kuzniar, ${ }^{55}$ for instance, describes the complexity of these relationships as follows:

the "gender trouble" of these films does not reside solely in their depiction of independent strong-willed women and their rejection of patriarchal authority. Both films deeply unsettle sexual as well as gender divisions in a way inconceivable for even independent gay cinema as well as mainstream straight cinema today. ${ }^{56}$

In both films, there is a constant power and role struggle between the lovers. This is set against the background of a society intensely caught up in a power struggle, (re-)militarisation and the control of the others.

Fräulein Von Bernburg and Felice seem to be the more dominant, more experienced women in the beginning, with Fräulein Von Bernburg, the adult and teacher, and Felice, the "out", self-confident lesbian. This becomes clear when Fräulein Von Bernburg gives Manuela one of her own chemises. She tries to channel her concern and affection into the quasi-permissible form of a maternal gesture, which, however, is also an erotic token. The conversation that follows between the two women is evidence of Fräulein Von Bernburg's repressive tolerance exercised toward the student's incipient homosexuality. When Manuela becomes too emotional, Fräulein Von Bernburg reaffirms her dominant position by reprimanding her, "What an excitable child you are." She scolds Manuela in various instances in an attempt to reject her advances on the basis of pedagogical concerns, for instance "You must be cured" or "I can't make exceptions, the others would be jealous."

Similarly, Felice seems the more mature woman when compared with Lilly. She leads Lilly from her life as an unfulfilled heterosexual mother of four children who takes on lovers in an unsuccessful chase to find sexual fulfilment with a man to life as a fulfilled, loving lesbian. She opens Lilly, who at times seems very naïve, to the political and societal reality around her. As in Mädchen in Uniform, the more well-off Felice also gives her old clothes to Lilly, who cherishes them. Even the nicknames the lovers give each other echo the power roles: Felice, takes on the dominant, dangerous predatorial "Jaguar", while Lilly is simply Aimée. ${ }^{57}$ Furthermore, in German, "Jaguar" is a masculine word, signified by the article "der", while Aimée is a feminine name.

As the plot unfolds, roles reverse and Manuela and Lilly become increasingly dominant. Felice is forced to go into hiding and has to depend on Lilly 
for shelter, food and protection. When the former is finally discovered and arrested, Lilly is the one fighting for her partner's life. Similarly, Manuela grows more confident of her own and Fräulein Von Bernburg's feelings. Finally, she is the one who takes on the dominant male role or Hosenrolle (the "breeches role", also "pants role" or "trouser role"), a term used in drama for women acting the parts of men. Playing Don Carlos in a school production, and therefore dressed as a boy, she openly declares her love for Fräulein Von Bernburg. As in many Weimar films, "so too here the gender invert, the boy object, visibly encodes the homosexual". ${ }^{8}$ This Hosenrolle, which proved popular in queer films during the Weimar Republic, performed a double function. In addition to stirring up ambiguous feelings, it also

Dramatized [women's] precarious social and economic status in terms of the patriarchal dilemma: women's access to the world of power, actions and wealth is gained either through a husband or transvestite clothes. ${ }^{59}$

\section{Conclusion}

Authoritarian ideologies and the societies they try to mould into their image tend to destroy memories, relationships and future possibilities not only during their existence, but also during their downfall. In spite of great advancements made in the area of queer films during the Weimar Republic, much material was lost or destroyed by the National Socialists. To this day, male homosexual filmmaking still takes precedence over lesbian filmmaking. The power struggle between genders, but also sexualities as depicted in the films is still far from over. It seems ironical that the pupil (Manuela) is finally exposed as the dominant, more confidant lover, while Aimée proves too dangerous for her predatorial Jaguar, who pays with her life for her decision to stay with her. It seems questionable whether Manuela and Fräulein Von Bernburg would really have had a happy end. Dyer describes how the Hosenrolle in films, in spite of seeming to promise freedom and emancipation, also ultimately turns out to be a mere illusion:

This double danger that the Hosenrolle films flirted with - social and sexual independence from men - is resisted in the texts of the films. Most end with the woman restored to her "right" place in patriarchal society, and, as Annette Kuhn has argued in the context of Hollywood cinema, much of the film's pleasure plays on the spectator's knowledge of who is really what, reassuring us that "the body beneath the clothes is indeed the site of ultimate sexual difference, and the difference is after all absolute". 60 
Despite criticisms, the achievements of LGBTI filmmakers during the Weimar Republic made a social impact and influenced social identity groups. They also undermined old stereotypes and one wonders where German queer film on its march to freedom would be had National Socialism not interrupted its development at such an early stage.

At a deeper level our article addressed the issue of memory against the destruction of records and the erasing of social and individual memories when topdown governments/leaders/projectors of international military power attempt to mould all and sundry into their uniform image. Predictably, authoritarians with their military might tend to destroy mirrors that do not reflect their ideology. Strangely, however, broken mirrors cannot erase memories or prevent the rise of new social identities as demonstrated in this article.

The contexts of being demonstrate that socialisation, the role definition of the self and the choice to associate with other identity groups are seldom as glib as those caught up in an ideological group - or groupthink - would like them to be. Frequently such choices, despite complexities, present both critical questions and challenges to those who wish to impose morality from the top, and those at the top fail to predict the extent of future resistance.

Lastly, the article raised the still open question of why heroes in films, even in the LGBTI tradition, are sometimes portrayed as the strong (or hierarchically rehabilitated) if the underlying message was exactly the opposite, namely the destruction of such imposed dominating roles. Here the horizons for further investigation remain open.

\section{Endnotes}

\footnotetext{
${ }^{1}$ Bumstead, PJ. Hitler: A short biography. London: University Tutorial Press, 1972, 10ff; Tooze, A. The wages of destruction: The making and the breaking of the Nazi economy. London: Penguin Books, 2007, 2; Bundestag. Fragen an die deutsche Geschicte: Ideen, Kräfte, Entscheidungen von 1800 bis zur Gegenwart. Bonn: Bundestag Publications Section, 1989, 248.

${ }^{2}$ For a detailed treatment of objections on how the Peace of Versailles (1919) deviated from the originally envisaged Fourteen Points of Woodrow Wilson and how one of the Allied delegates Jan Christiaan Smuts forewarned Lloyd George, Wilson and Clemenceau of the peace terms' inherent flaws of "onesidedness and dictation”, see Lentin, A. Jan Smuts: Man of courage and vision. Johannesburg: Jonathan Ball, 2010, Chapter 3, 49ff, 88. It was not to be a Wilsonian Peace but one that held the germs of future conflict. For the situation in an economically troubled Germany under the Weimar Republic,
} 
see Tooze op. cit., pp. xxiff, 10ff. See also Cochrane, J \& Kerr-Jarrett, A. The fragile peace, 1919-1939. Sydney: Toucan Books, 1999.

${ }^{3}$ Germany was not alone in this experience. In Italy, Fascism as an ideology spearheaded by Benito Mussolini was on the rise a decade earlier and eventually would take power. In Spain, the Francoist and Falangist movements were to come to power following the defeat of the democratic, republican, communist and anarchist forces and under Franco Spain became an authoritarian state. Few social freedoms were allowed. Even while Franco rose to power, soldiers, poets, artists and journalists were not safe. Lorca, a famous Spanish poet, was murdered. In the course of the civil war, Guernica, a town of little strategic value but known for its art, was bombed to smithereens with the help of Nazi Germany's air force (Luftwaffe). Artists such as Picasso were persecuted. Authoritarian societies tend to do so. South Africans still remember the habitual banning of books, artworks and organisations that were seen as 'subversive' or politically incorrect under a (white) Christian Nationalist regime that evolved into a security state between 1948 and 1988.

${ }^{4}$ Bundestag op. cit., pp. 256-257, 258, 274.

${ }^{5}$ Some sources refer to the Freikorps being guilty of Luxemburg and Liebknecht's murders. See Gorman, RA (ed.). Biographical dictionary of Marxism. London: Mansell, 1986, 202. Consult also Bundestag op. cit., p. 257. For an example of Luxemburg's work in the anti-revisionist Marxist tradition and her theoretical differences with Eduard Bernstein, a social democrat, see Luxemburg, R. Reform or revolution (English ed.). Montreal: Pathfinder Press, 2001. The introduction to this work by Mary-Alice Waters (pp. 7-10) is also relevant.

${ }^{6}$ McCormick, RW. “'Calligari' to Dietrich: Sexual, social, and cinematic discourses in Weimar film”. Signs. 18/3. 1993, 645.

${ }^{7}$ Critique and crisis are closely related. "Kritiek treedt vooral op in een krisessituatie ... het maatschappelijke organisme staat voor de verplichtende keuze van ja oor neen ... de nieuwe voelen de krises de sterkste aan (Plattel, M. Utopie en kritisch denken. Bilthoven: Ambo-pers, 1970, 112.) Indeed in the Weimar Republic, as much as in other societies such as South Africa under apartheid, crises and critique go hand in hand and numerous were the consequences of top-down impositions including imposed gender roles.

${ }^{8}$ McCormick op. cit.

${ }^{9}$ Merck, M. “'Lianna' and the lesbians of art cinema”. In Brunsdon, C (ed.), Films for women. London: BFI Publishing, 1987, 166.

${ }^{10}$ Smelik, A. "Gay and lesbian criticism". In Hill, J \& Church Gibson, P (eds), Film studies: Critical approaches. Oxford: Oxford University Press, 2000, 135.

${ }^{11}$ Compare Zimmik, N. "No man, no cry? The film girls in uniform and its discourses of political regime". Women in German Yearbook. 15. 1999, 162.

${ }^{12}$ For the centrality of gender discourse in contemporary sociology, see Schaefer, RT. Sociology ( $9^{\text {th }}$ ed.). New Delhi: McGraw-Hill, 2005, 281ff; Hughes, M \& Kroehler, CJ. Sociology: The core ( $7^{\text {th }}$ ed.). Kuala Lampur: McGraw-Hill, 
$2005,252 \mathrm{ff}$. The gender debate in contemporary political science is addressed by Baradat, LP. Political ideologies: Their origins and impact $\left(9^{\text {th }}\right.$ ed.). London. Pearson/Prentice Hall, 2006, 267ff. For an application of the gender debate in South Africa in the aftermath of patriarchy and militarization, see Madlala-Routledge, N. "Beyond patriarchy and militarization". Focus 57. 2010, 26-31.

${ }^{13}$ For earlier examples of the militarist, even racist, ethos prevalent in German colonialism before the rise of National Socialism, consult Olusoga, D \& Erichsen, CW. The Kaiser's Holocaust: Germany's forgotten genocide and the colonial roots of Nazism. London: Faber and Faber, 2010, as well as Sarkin, J. Germany's genocide of the Herero: Kaiser Wilhelm II, his general, his settlers, his soldiers. Cape Town: UCT Press and James Currey, 2011. These works demonstrate how the brutality of German colonial rule was based on tenets of authoritarianism, military hard-handedness and elements of Eurocentrism and racism. The colonial mentality of Germans was not unique. The British Empire of the time provides many examples, in cases even influencing the German elite of the time (compare Milton, R. Best of enemies, Britain and Germany. Cambridge: Icon Books, 2008, 19, $139,180 \mathrm{ff})$. One may note that the rule of Belgian colonialists at the time was not much better.

${ }^{14}$ Hanna, T. Bodies in revolt: A primer in somatic thinking. New York: Delta Books, $1972,9,11,19,246,278,307$. While the authors take note of the notion of counter culture as a sociological concept, we do not primarily focus on this concept here. On counter culture see, Roszak, T. The making of a counter culture. London: Faber and Faber, 1969.

${ }^{15}$ Danforth, EM. "Essays: Mädchen in uniform". Quarterly Review of Film and Video 27. 2010, 353.

${ }^{16}$ Under apartheid alternative films remonstrating against authoritarian state and the security state played an important role. For a pioneering work on films against apartheid, consult, Botha, M \& Van Aswegen, A. Beelde van SuidAfrika: 'n Alternatiewe rolprentoplewing. Pretoria: Raad vir Geesteswetenskaplike Navorsing, 1992.

${ }^{17}$ Rich, R. "Maedchen in Uniform: From repressive tolerance to erotic liberation." Jump Cut: A Review of Contemporary Media 24/25. 1981, 44.

${ }^{18}$ A 1958 remake of the movie starring Romy Schneider is available on DVD with English subtitles. Predictably, lesbian and antifascist themes were severely toned down in the production of this movie.

${ }^{19}$ Danforth op. cit., p. 353.

${ }^{20} \mathrm{Sieg}, \mathrm{K}$. "Dis/Identification: Sexual desire and social transformation in Aimée \& Jaguar". Gender and Cultural Memory. Special Issue 28/2. 2001, 304.

${ }^{21}$ McCormick op. cit., p. 641.

22 This reminds one of the first verse of the German national anthem at the time, starting with the words "Deutschland, Deutschland über alles". The expression could thus be seen as a rip-off of traditional German patriotism.

${ }^{23}$ Sloterdijk, cited in McCormick op. cit. 
${ }^{24}$ Here the authors do not address the philosophical or sociological implications of power struggle through the lenses of Foucault or Sartre, for example. That deserves further studies.

${ }^{25}$ Consult Cochrane \& Kerr-Jarret op. cit., pp. 36-37.

${ }^{26}$ McCormick op. cit.

${ }^{27}$ Low-income rental high-rise housing; it frequently resulted in horrific living conditions.

${ }^{28}$ Cochrane \& Kerr-Jarrett op. cit., pp. 36-37.

${ }^{29}$ Berman, S. "Civil society and the collapse of the Weimar Republic". World Politics 49/3. 1997, 401-429.

${ }^{30}$ Bergfelder, T \& Carter, E. “Cultural politics. Introduction”. In Bergfelder, T, Carter, E \& Göktürk, D (eds), The German cinema book. London: Palgrave Macmillan, 2008, 161-164.

31 At the time called motion pictures ("movies") or flicks.

${ }^{32}$ Silberman, M. "Political cinema as oppositional practice: Weimar and beyond". In Bergfelder et al. op. cit., p. 165.

${ }^{33}$ Ibid.

${ }^{34}$ Ibid.

${ }^{35}$ Dyer, R. "Less and more than women and men: Lesbian and gay cinema in Weimar Germany". New German Critique. Special Issue on Weimar Mass Culture 51. 1990, 5.

${ }^{36}$ Kiss, RJ. "Queer traditions in German cinema”. In Bergfelder et al. op. cit., pp. $48-56$.

${ }^{37}$ Paragraph 175 of the German penal code punished "unnatural sexual acts between persons of the male sex" with up to five years' imprisonment.

${ }^{38}$ Danforth op. cit., p. 353.

${ }^{39}$ Consult Petley, J. "Film policy in the Third Reich". In Bergfelder et al. op. cit., pp. 173-181.

${ }^{40}$ Zimmik op. cit., p. 162.

${ }^{41}$ Christa Winsloe, author of the novel the movie was based on, was also the daughter of a Prussian officer. Like Manuela, she attended a Prussian boarding school. After a mailed marriage, she had a long-term lesbian relationship.

${ }^{42}$ The absent father who cannot look after his own once again ties in neatly with the existential fear experienced by many men during the Weimar years.

${ }^{43}$ Rich op. cit., p. 46.

${ }^{44}$ Zimmik op. cit., p. 163.

${ }^{45}$ Davidson, JE. "A story of faces and intimate spaces: Form and history in Max Färberböck's Aimée \& Jaguar”. Quarterly Review of Film and Video 19. $2002,323$.

${ }^{46}$ Sieg op. cit., p. 304. The National Socialist government imposed a prohibition on racial sexual relationships/affairs, as was done in colonial times and much later also by apartheid South Africa. Compare Sarkin op. cit., p. 25; Adam, $\mathrm{H} \&$ Giliomee, H. Afrikanermag: Opkoms en toekoms. Grahamstown: UUB, 
1981, 41; De Villiers, E \& Kinghorn, J. Op die skaal: Gemengde huwelike en ontug. Cape Town: Tafelberg, 1984, 28ff.

47 The ban on interracial relationships was not unique. The National Party and the secret male-Christian-white-Protestant Afrikaner Broederbond in coming to power in South Africa (1948) 20 years after the first beginnings of the National Socialist movements in Germany and the Netherlands introduced similar laws in the Cape Colony. Consult Villiers \& Kinghorn op. cit.

${ }^{48}$ Davidson op. cit., p. 333

${ }^{49}$ Ibid.

${ }^{50}$ Zimmic op. cit., p. 163.

${ }^{51}$ Rich op. cit., p. 45.

${ }^{52}$ The three concepts that should be, in then traditional German (before the Weimar Republic), of interest to woman: children, church and the kitchen. It was later picked up again in Nationalist Socialist discourse with the rise of Hitler.

${ }^{53}$ Rich op. cit., p. 45.

${ }^{54}$ Ibid., p. 44.

${ }^{55}$ Kuzniar, AA. The queer German cinema. Stanford: Stanford University Press, $2000,33$.

56 The assaults on Weimar democracy came from many sides. The deep divisions between the loyalties that the working class faced during the rise of Nazism and Fascism are one symptom of the era. Here the 'I' as subject versus the other and the 'we' as subjects versus them as the pour-soi of one negating the other pour-soi is notable. (Compare Howard, D. The Marxian legacy. Dublin: Macmillan, 1977, 158 on Sartre and the subject/object existence.) In the Weimar Republic, these differences were not only theoretical, but a reality in practice as in many other societies before and afterwards. Reflect for a moment on apartheid and its consequences that translate in still divisive discourses on various levels. Reflect for example on the incidences of European states attacking African people on African soil under a United Nations resolution (No. 1973), ostensibly to protect Africa from Africa.

${ }^{57}$ French word for 'Beloved'.

${ }^{58}$ Kuzniar op. cit., p. 39.

${ }^{59}$ Miriam Hansen, cited in Dyer op. cit., p. 47.

${ }^{60}$ Dyer op. cit., p. 47. 